\title{
The acceptability of personal learning plans in vocational training
}

\author{
A Niroshan Siriwardena
}

\begin{abstract}
Summary
Personal learning plans have been advocated as a means of introducing the principles of adult learning into general practice vocational training. The aim of this study was to investigate attitudes amongst general practice trainers and registrars to the introduction and use of personal learning plans. A questionnaire was sent to general practice trainers and registrars in one vocational training scheme prior to the introduction of personal learning plans. Overall, doctors in the training scheme were positive to the idea of personal learning plans. Trainers were significantly more positive towards introducing learning plans than their registrars. Registrars in their final general practice posts were significantly more positive towards the idea of learning plans than their hospital counterparts. Doctors who had completed membership of the Royal College of General Practitioners, usually trainers or final year registrars, were also more positive in their attitude. This pilot study suggests that most trainers and registrars were positive in their attitude towards personal learning plans prior to their introduction in the Lincoln vocational training scheme. The study cautiously suggests a wider use and evaluation of personal learning plans in vocational training.
\end{abstract}

Keywords: personal learning plan, portfolio-based learning, training, registrars

Medical education, as with other forms of adult learning, is largely self-directed and evaluated. It is most effective when it is based on perceived need, builds on existing knowledge and experience, uses methods that are preferred by the individual learner, and leads to knowledge and skills which can be easily applied in practice. ${ }^{1}$ An innovative way of organising vocational training for general practice, employing the principles of adult learning, is by using personal learning plans. A personal learning plan for vocational training may be defined as a negotiated agreement between the general practice registrar, the trainer, and the course organiser, regarding the objectives, methods and assessment of study during training.

Previous criticisms of vocational training have been concerned with the absence of an effective educational framework, poor integra- tion between general practice and hospital training, and the fact that training inadequately reflects and prepares registrars for the rapidly changing environment of primary care. To address these criticisms, the Royal College of General Practitioners (RCGP) has recommended that training should be more service orientated and multidisciplinary, with better integration of hospital and general practice posts, and determined by the educational needs of the individual registrar.

Vocational training is a critical starting point for self-directed learning that will continue throughout a general practitioner's career. The examination of individual learning needs and how these are addressed are crucial to this process. ${ }^{3}$ Organising training to meet the learning needs of registrars has been advocated by general practice educators for some time. ${ }^{4}$ It has also been discussed by general practice trainers ${ }^{5}$ and no doubt practised, though not always explicitly or written down. The personal learning plan has been advocated as a method for introducing the principles of adult learning into vocational training and also for continuing medical education after completion of vocational training. ${ }^{6}$ These concepts have been successfully introduced into higher education and the workplace in the UK. ${ }^{7}$

Little is known about the attitudes of general practice trainers and registrars to personal learning plans. Attitudes towards this type of self-directed curriculum will be an important factor in its successful introduction into vocational training. The aim of this pilot study was to investigate the attitudes of a small group of trainers and registrars in the Lincoln vocational training scheme prior to the introduction of personal learning plans.

\section{Method}

The principles of portfolio-based learning, its advantages and disadvantages and the possibility of using personal learning plans in vocational training were discussed in outline at a trainers' workshop and in detail at a residential course for trainers from the Lincoln vocational training scheme in early 1995 . Further discussions were held by the trainers and registrars separately and together to explore the potential of learning plans on the scheme. It was decided to pilot the use of personal learning plans in the general practice component of vocational training. The format included sections on outline objectives, case analysis, learning needs, topic learning and learning assessment. 
Trainers and registrars were invited to complete a questionnaire prior to introduction of personal learning plans in July 1995. Questionnaires were accompanied by a covering letter in which learning plans were defined as 'an agreement negotiated between the registrar, the trainer and course organiser regarding the objectives, methods and assessment of study during training.' The covering letter also gave a brief resumé of the reasons for using learning plans, their advantages, and a draft outline of a previously agreed format.

The first part of the questionnaire comprised a series of attitude statements on learning plans for 10 areas of concern identified by the preliminary group discussions amongst trainers and registrars. A 'balanced' questionnaire using paired statements expressing opposite attitudes was employed to account for acquiescent bias as has been used elsewhere. ${ }^{8}$ The pairs of statements were randomly ordered for each of the 10 areas. A Likert-type ${ }^{9}$ format with five response codes ranging from 'strongly agree' (scoring one point) to 'strongly disagree' (scoring five points) was used for each statement and an open question asking for other comments was included. The second section consisted of factual questions on the respondent's attributes and preferences for the content of learning plans. This included age, gender, membership (or fellowship) of the RCGP and status as trainer or registrar.

Total attitude scores for each respondent were derived by reversing the scores for positive statements and adding together the score for each statement. Mean total scores and standard deviations were calculated for each subgroup. Mean scores were also calculated for each statement with a higher score signifying a more positive attitude towards learning plans. A mean score of more than 3.0 indicated a positive attitude. Completed questionnaires were analysed using Epi-info version 6 . The non-parametric Kruskal-Wallis test was used for subgroup analysis.

\section{Results}

All of the doctors handed questionnaires returned them. Characteristics of the doctors and their practices are shown in table 1, and respondents' attitudes to learning plans are shown in table 2. Most of the respondents appeared to be positive towards learning plans, given that mean scores for the statements, except those on continuing medical education, exceeded 3.0. The pattern of responses was also consistent, ie, a positive response to a statement was matched by a negative response to its pair.

A comparison of attitude scores of trainers and registrars in table 3, using a non-parametric (Kruskal-Wallis) test, showed that trainers were significantly more positive towards learning plans than registrars. Registrars in general practice posts had significantly higher scores than their hospital counterparts (table 4), whereas trainers and registrars in general practice were not significantly different in terms of their attitude scores (table 5).
Finally, doctors (whether trainers or registrars) who had achieved membership of the RCGP were more positive towards learning plans than those who had not (table 6).

\section{Discussion}

Despite the increasing interest in their use, there is little or no published evidence for the use of personal learning plans in vocational training. Learning plans originated in the US but have been used, evaluated and shown to be successful in higher education and in the workplace in the UK. ${ }^{7}$ Learning plans encompass the principles of adult learning by encouraging learners to assess their own needs, set personal objectives, negotiate an individually tailored curriculum and allowing the learner to identify resources and strategies to achieve and evaluate these objectives. ${ }^{10}$ Learning plans also allow incorporation of other recognised educational techniques such as experiential learning, ${ }^{11}$ and problem- and portfolio-based learning. ${ }^{12}$ Learning plans do not mean, of course, that all learning has to be meticulously planned beforehand, since it is inevitable that important learning may be unexpected and unplanned. A working party of the RCGP recommended a flexible learnercentred approach to training which is embraced by the concept of the learning plan. ${ }^{13}$ This approach was also endorsed by the College in its policy statement on education and training and an editorial in the College journal. ${ }^{14}$

Studies of doctors in vocational training tend to support the use of learner-centred methods. Almost half the doctors in one study from the West of Scotland felt that certain areas had been inadequately covered in the practice component of their training. ${ }^{15}$ Baker and Sprackling, in their survey of the hospital component of vocational training, found that $87 \%$ of trainees would have welcomed educational objectives for their training posts whereas only $23 \%$ recognised the existence of such objectives for their post at the time of the survey. ${ }^{16}$ Such deficiencies in training would be obviated by registrars having more say about their individual learning needs and how these would be addressed in their personal curricula. Vocational training by concentrating on pro-

Table 1 Characteristics of registrars and trainers responding to the questionnaire on learning plans

\begin{tabular}{|c|c|c|}
\hline & $\begin{array}{l}\text { Trainers } \\
(n=7)\end{array}$ & $\begin{array}{l}\text { Registrars } \\
(n=13)\end{array}$ \\
\hline Male & 6 & 7 \\
\hline Age (years) $25-34$ & 1 & 13 \\
\hline $35-44$ & 4 & 0 \\
\hline $45-54$ & 2 & 0 \\
\hline$>55$ & 0 & 0 \\
\hline $\begin{array}{l}\text { Member (or fellow) of } \\
\text { the RCGP }\end{array}$ & 6 & 4 \\
\hline Rural & 3 & 9 \\
\hline Fund-holding & 6 & 4 \\
\hline
\end{tabular}

Not all respondents answered every question 
Table 2 Paired statements on attitudes to learning plans in questionnaire showing responses (\%), and mean scores (scale of $1-5$ )

\begin{tabular}{|c|c|c|c|c|}
\hline \multirow[b]{2}{*}{ Statement } & \multicolumn{3}{|c|}{ No (\%) of general practitioners } & \multirow[b]{2}{*}{$\begin{array}{l}\text { Mean } \\
\text { score }\end{array}$} \\
\hline & $\begin{array}{l}\text { Agree } \\
\text { or strongly } \\
\text { agree }\end{array}$ & Neutral & $\begin{array}{l}\text { Disagree } \\
\text { or strongly } \\
\text { disagree }\end{array}$ & \\
\hline \multicolumn{5}{|l|}{ Recording } \\
\hline $\begin{array}{l}\text { Learning plans will be a useful way of recording } \\
\text { learning (teaching) objectives }\end{array}$ & $15(75)$ & $2(10)$ & $3(15)$ & 3.65 \\
\hline $\begin{array}{l}\text { A learning plan would be an irrelevant checklist } \\
\text { Core versus options }\end{array}$ & $3(15)$ & $5(25)$ & $12(60)$ & 3.80 \\
\hline $\begin{array}{l}\text { Learning plans would improve coverage of a core } \\
\text { curriculum }\end{array}$ & $14(70)$ & $4(20)$ & $2(10)$ & 3.65 \\
\hline $\begin{array}{l}\text { Learning plans would mean dull conformity for } \\
\text { vocational training }\end{array}$ & $3(15)$ & $5(25)$ & $12(60)$ & 3.60 \\
\hline \multicolumn{5}{|l|}{ Practical implications } \\
\hline $\begin{array}{l}\text { Learning plans are an extension of what I am } \\
\text { already doing }\end{array}$ & $13(65)$ & $5(25)$ & $2(10)$ & 3.60 \\
\hline $\begin{array}{l}\text { Learning plans would interfere with what I am } \\
\text { learning (or teaching) as a registrar (or trainer) }\end{array}$ & $2(10)$ & $5(25)$ & $13(65)$ & 3.65 \\
\hline \multicolumn{5}{|l|}{ Experience and effectiveness } \\
\hline $\begin{array}{l}\text { A learning plan used properly would enhance my } \\
\text { experience (effectiveness) as a learner (teacher) }\end{array}$ & $10(50)$ & $6(30)$ & $4(20)$ & 3.30 \\
\hline $\begin{array}{l}\text { Learning plans sound like a waste of time and effort } \\
\text { Content }\end{array}$ & $3(15)$ & $3(15)$ & $14(70)$ & 3.85 \\
\hline $\begin{array}{l}\text { Using learning plans would make teaching more } \\
\text { relevant to the needs of registrars }\end{array}$ & $9(45)$ & 7 (35) & $4(20)$ & 3.35 \\
\hline $\begin{array}{l}\text { The use of learning plans will not affect the content of } \\
\text { learning (or teaching) in my training practice }\end{array}$ & $3(15)$ & 7 (35) & $10(50)$ & 3.35 \\
\hline \multicolumn{5}{|l|}{ Co-ordination } \\
\hline $\begin{array}{l}\text { Learning plans would reduce unnecessary repetition } \\
\text { during training }\end{array}$ & $11(55)$ & $3(15)$ & $6(30)$ & 3.20 \\
\hline $\begin{array}{l}\text { Teaching in the training practice and half day release } \\
\text { is well co-ordinated }\end{array}$ & $8(40)$ & $3(15)$ & $9(45)$ & 3.10 \\
\hline \multicolumn{5}{|l|}{ Revision } \\
\hline $\begin{array}{l}\text { A written learning plan would be a useful revision aid } \\
\text { I wouldn't bother to look at what was written in a }\end{array}$ & $10(50)$ & $6(30)$ & $4(20)$ & 3.20 \\
\hline $\begin{array}{l}\text { learning plan } \\
\text { Assessment }\end{array}$ & $4(20)$ & $3(15)$ & $13(65)$ & 3.75 \\
\hline $\begin{array}{l}\text { A learning plan would be a useful written record of } \\
\text { achievement }\end{array}$ & $10(50)$ & 7 (35) & $3(15)$ & 3.45 \\
\hline $\begin{array}{l}\text { I am worried that learning plans may be used for } \\
\text { summative assessment }\end{array}$ & $5(25)$ & $8(40)$ & $7(35)$ & 3.10 \\
\hline \multicolumn{5}{|l|}{ Resources } \\
\hline $\begin{array}{l}\text { Identifying learning needs would lead to better } \\
\text { resources for training }\end{array}$ & $12(60)$ & $5(25)$ & $3(15)$ & 3.45 \\
\hline $\begin{array}{l}\text { Learning plans will lead to fewer resources for } \\
\text { teaching }\end{array}$ & $1(5)$ & $9(45)$ & $10(50)$ & 3.60 \\
\hline \multicolumn{5}{|l|}{ Continuing medical education } \\
\hline $\begin{array}{l}\text { A learning plan would be a useful method for planning } \\
\text { my future continuing medical education as a } \\
\text { principal }\end{array}$ & $7(35)$ & $8(40)$ & $5(25)$ & 3.05 \\
\hline $\begin{array}{l}\text { I am unlikely to use learning plans having completed } \\
\text { vocational training }\end{array}$ & $8(40)$ & $4(20)$ & $8(40)$ & 3.00 \\
\hline
\end{tabular}

blem-solving with one-to-one teaching in the training practice and small group work at halfday release courses lends itself naturally to selfdirected learning and there is evidence that independent learning is favoured by registrars. ${ }^{17}$ There is considerable overlap between the idea of using a personal learning plan, a training $\log { }^{18}$ and a portfolio. Whether one uses a more formal approach with defined priority objectives ${ }^{19}$ or a developmental, 'here and now', approach to curriculum planning, ${ }^{20}$ a learning plan can be used as a framework to individualise learning and teaching. The learning plan, perhaps in the form of a completed portfolio, may be used as evidence of the content and achievements of training. ${ }^{21}$

The small numbers involved in this pilot survey preclude generalisation of the results outside the training scheme in which it was carried out. However, the general attitudes expressed and the interesting differences between subgroups merit further discussion.

Overall, doctors in this study were positive to the idea of personal learning plans before their introduction in the vocational training scheme. In particular, most respondents felt that learning plans would be a useful way of recording learning (and teaching) objectives, that they would improve coverage of a core curriculum, enhance experience (effectiveness) as a learner (or teacher), and reduce unnecessary repetition during training. Most respondents felt that learning plans were an extension of what they were already doing.

The most commonly held negative beliefs were that learning plans may be used for summative assessment and that they were unlikely to be used after completing vocational 
Table 3 Comparison of mean total scores of trainers and registrars

\begin{tabular}{lll}
\hline & $\begin{array}{l}\text { Trainers } \\
(n=7)\end{array}$ & $\begin{array}{l}\text { Registrars } \\
(n=13)\end{array}$ \\
\hline Mean total score & 76.857 & 64.308 \\
Standard deviation & 8.071 & 14.103 \\
\hline
\end{tabular}

Kruskal-Wallis $\mathrm{H}$ (equivalent to $\mathrm{Chi}$ square) $=4.426$, d.f. $=1, p=0.035$

Table 4 Comparison of mean total scores of registrars in general practice with those in hospital posts

\begin{tabular}{lll}
\hline & $\begin{array}{l}\text { Registrars in } \\
\text { practice } \\
(n=5)\end{array}$ & $\begin{array}{l}\text { Registrars in } \\
\text { hospital posts } \\
(n=8)\end{array}$ \\
\hline Mean total score & 78.2 & 55.6 \\
Standard deviation & 4.6 & 10.2
\end{tabular}

Kruskal-Wallis $\mathrm{H}$ (equivalent to Chi square) $=8.643$, d.f. $=1, p=0.0033$

training. There is evidence to suggest, however, that personal learning plans are a welcome and successful method of continuing medical education. ${ }^{22}$ Indeed, many regional advisors are already approving postgraduate education allowance for practitioners submitting and completing such plans as part of their higher professional education.

Trainers were significantly more positive towards learning plans than their registrars. Registrars in general practice posts in this small survey were all final year vocational trainees at the point of completing their training. They were significantly more positive towards the idea of learning plans than their hospital counterparts. Doctors who had completed membership of the RCGP, usually trainers or final year registrars, were also more positive. It could be argued that doctors who were more experienced in self-directed learning were more positive to the concept of learning plans. Although there is substantial evidence of the

1 Knowles $M$. The adult learner: a neglected species. Houston: Gulf Publishing, 1990; p31.

2 Royal College of General Practitioners. Education and training for general practice. Policy statement 3. Bishop Auckland: RCGP, 1994; pp 2-4

3 Savage R. Continuing education for general practice: a life long journey. Br $\mathcal{F}$ Gen Pract 1991; 41: $311-4$

4 Hull R. Training for general practice - no place for national curriculum. BMF 1989; 299: 996.

5 Styles WM. General practice training in the hospital. $\mathrm{Br} f$ Gen Pract 1990; 40: 401-2.

6 Gen Pract 1990; 40: 401-2. 1994; 309: 284-5.

7 Laycock $M$, Stephenson J. Using learning contracts in higher education. London: Kogan Page, 1993.

8 Pringle M, Robins S, Brown G. Computers in the surgery. The patient's view. BMF 1984; 288: 289-91.

9 Likert R. A technique for the measurement of attitudes. Arch Psychol (New York) 1932; 140: 44-53.

10 Knowles MS. Andragogy in action: applying modern principles of adult learning. San Francisco, CA: Jossey-Bass, 1984.

11 Al-Shehri A, Stanley I, Thomas P. Continuing education for general practice. Systematic learning from experience. Br fGen Pract 1993; 43: 249-53.

12 Lowry S. Strategies for implementing curriculum change. Low S. Strategies for in

13 Pietroni R. New strategies for higher professional education. Br f Gen Pract 1992; 42: 294-6.
Table 5 Comparison of mean total scores of trainers with registrars in general practice

\begin{tabular}{lll}
\hline & $\begin{array}{l}\text { Trainers } \\
(n=7)\end{array}$ & $\begin{array}{l}\text { Registrars in } \\
\text { practice }(n=5)\end{array}$ \\
\hline Mean total score & 76.9 & 78.2 \\
Standard deviation & 8.1 & 4.7
\end{tabular}

Kruskal-Wallis $\mathrm{H}$ (equivalent to Chi square) $=0.167$, d.f. $=1, p=0.68$

Table 6 Comparison of mean total scores of members of the RCGP with non-members (whether trainer or registrar)

\begin{tabular}{lll}
\hline & $\begin{array}{l}\text { RCGP } \\
\text { members } \\
(n=10)\end{array}$ & $\begin{array}{l}\text { Non-RCGP } \\
\text { members } \\
(n=10)\end{array}$ \\
\hline Mean total score & 79.3 & 58.1 \\
Standard deviation & 4.4 & 10.9
\end{tabular}

Kruskal-Wallis $\mathrm{H}$ (equivalent to Chi square) $=12.94$, d.f. $=1, p=0.00032$

value of personal training plans, if they are perceived as a threat by either trainers or registrars, their introduction into vocational training will obviously be problematic. Attitudes may change as personal learning plans gain wider acceptance in postgraduate training for general practice. Learning plans, used well, would certainly be one way of matching the 'traditional strengths of medical education' with the 'shifting needs of potential general practitioners'.23 This pilot study supports the use of personal learning plans in vocational training. A study covering a wider area and using qualitative and quantitative methods would help to assess their usefulness in practice.

I would like to thank the trainers, registrars and course organisers from the Lincoln vocational training scheme who kindly agreed to participate in this study. Also Dr R Whitbread and Dr M Baker for their advice and comments.

14 Styles WM. Education and training for general practice: Royal College of General Practitioners' policy statement. $\mathrm{Br}$ 7 Gen Pract 1994; 44: 542 - 3

15 Kelly DR, Murray TS. Twenty years of vocational training in the West of Scotland: the practice component. $B r f G e n$ Pract 1991; 41: 492-5.

16 Baker M, Sprackling PD. The educational component of 6 Baker M, Sprackling PD. The educational component of
senior house officer posts: differences in the perceptions of consultants and junior doctors. Postgrad Med $\mathcal{F}$ 1994; 70: $198-202$.

17 Bligh JG. Independent learning among general practice trainees: an initial survey. Med Educ 1992; 26: 497-502.

18 Havelock P, Hasler J, Flew R, McIntyre D, Schofield T, Toby J. Professional education for general practice. Oxford: OUP, 1995; pp 93-7.

19 Oxford Region Course Organisers and Regional Advisers Group. Priority objectives for vocational training. London: RCGP, 1988; pp 9-11.

20 Samuel O. Towards a curriculum for general practice training. Occasional paper 44. London: RCGP, 1990; pp 20-4.

21 Royal College of General Practitioners. The use of portfolio-based learning in vocational training. In: Pietroni $\mathrm{R}$, ed. Portfolio-based learning in general practice. Occasional paper 63. Exeter: RCGP, 1993; pp 11-18.

22 Bahrami J. Can you plan your own education? Update 1995; 51: 334 .

23 Bain J. Vocational training: the end or the beginning? $B r f$ Gen Pract 1996; 46: 328-30. 